\title{
Readiness of Lecturers As A Facilitator In Interprofessional Education Learning In Antenatal Care
}

\author{
Dina Zakiyyatul Fuadah, Muhammad Taukhid ${ }^{1}$ \\ ${ }^{I}$ STIKES Karya Husada Kediri, East Java, Indonesia \\ Corresponding author : dinazakiyya@gmail.com
}

\begin{abstract}
Background: Many educational institutions in Indonesia are familiar with the concept of interprofessional learning or interprofessional education but not many have applied. Facilitator readiness, one of the causes of this method has not been implemented optimally. Purpose: This study aims to determine the readiness of the lecturer as a facilitator in interprofessional learning.

Methods: The pre-experimental design, pre and posttest design was used to examine a sample of 20 respondents which included the lecturers of nursing, midwifery and nutrition obtained by purposive sampling. Instrument to measure the readiness of lecturers using the RIPLS questionnaire.

Result: The results of statistical tests using the T-Test found that the readiness of lecturers in the positive category where there was a change in readiness before and after being given an intervention in the form of interprofessional learning training with a $\mathrm{P}_{\text {value }}$ of 0.021 .

Conclusion: Educational institutions are recommended to start developing interprofessional education models that are mutually agreed upon and supported by clear facilities, policies and regulations. Subsequent research is expected to explore more appropriate interprofessional learning models through both qualitative and quantitative approaches.
\end{abstract}

Keywords : Readiness of Lecturers, Facilitators, Interprofessional Education

Received July, 25, 2018; Revised August 24, 2018; Accepted September 14, 2018

How to Cite: Fuadah, D., Taukhid, M. (2018). Readiness of Lecturers As A Facilitator In Interprofessional Education Learning In Antenatal Care. Journal Of Nursing Practice, 2(1), 51-57. https://doi.org/10.30994/jnp.v2i1.43 


\section{BACKGROUND}

The ability to work interprofessionally (interprofessional teamwork) does not come out of nowhere, but must be found and trained early from the lecture stage so that students have the knowledge and experience on how to work in good team with other professions before they enter the world of work (Wagner, 2011). World Health Organization (2010) states that IPE is a process in which a group of students or health workers with different backgrounds learn together in a certain period of time during education, with interaction as the main goal, for collaboration in providing preventive, promotive, rehabilitative and other health services. In antenatal care, the IPE learning method is carried out by nursing, midwifery, nutritionists. One important factor in IPE learning is the role of facilitators conducted by lecturers. The role of the facilitator facilitates the learning process in students. The introduction of IPE learning to lecturers is an effort to improve the readiness of lecturers as facilitators through training, where this method is an effective way to improve the readiness of lecturers in assisting students in IPE learning. Through training allows lecturers to be able to explore collaborative ways to improve the communicative aspects of clinical care that must be taught to students as prospective health workers (Liaw, S.Y., et al, 2011).

Currently the development of the IPE curriculum has not been developed evenly in educational institutions. WHO (2010) issued data on the application of IPE in several countries, namely at the institutional level of $10.2 \%$ of doctors, $16 \%$ of nurses or midwives, $5.7 \%$ of nutritionists, and other health workers had received IPE-based learning. In the university setting results from surveys from 42 countries stated that as many as $24.6 \%$ had obtained the IPE curriculum at the academic stage. While in Indonesia it is not yet included, for this purpose there is a need to socialize the IPE learning method as a whole in all educational institutions considering that health science high schools are the main providers of prospective health workers who are expected to have good competence, especially the ability to collaborate with other health workers. Research conducted in the field of interprofessional education (IPE) has traditionally been concentrated on the learner's perspective (Gentry et al. 2001; Hind et al. 2003; Johnson et al. 2006). As a result, while the literature provides a detailed understanding of their IPE experience, little is known about the readiness and the facilitator's perspective on this type of learning. So there is still a need for research that identifies the readiness of lecturers as facilitators of interprofessional learning.

\section{OBJECTIVE}

This study aims to determine the readiness of the lecturer as a facilitator in interprofessional learning.

\section{METHODS}

Pre Experimental research design (pre posttest design), namely in this study intervention was carried out in the form of giving material about interprofessional education (IPE) learning, with pre-test conducted on the readiness of the lecturer as a facilitator of IPE learning, then continued with the posttest implementation about the readiness of the lecturer as learning facilitator IPE uses a readiness measurement instrument using the modified Readiness Interprofessional Learning Scale (RIPLS) questionnaire. The purposive sampling technique was used to determine the sample according to the inclusion and exclusion criteria with a sample size of 20 respondents. 
Data collection was carried out in April-May 2018 in the lecturers of the Karya Husada Kediri High School of Health Sciences. Data collection begins with informed consent to respondents, followed by Focus Group Discussion (FGD) as much as one time in preparation for the intervention and respondents were given a questionnaire for initial data collection (pretest). The intervention was in the form of training in IPE learning on antenatal care for two days, the first day of material giving, the second day of application in the form of role play of IPE learning using cases. Final data collection (posttest) was carried out two days after intervention. Furthermore, the data was analyzed using computerized assistance

\section{RESULTS}

Respondents in this study amounted to 20 lecturers who completed the research process from pretest to posttest. Respondents consisted of lecturers from the Nursing study program, Midwifery study program, Nutrition study program. This data collection was completed in April - May 2018. The characteristics of respondents in this study which included the origin of the study program, length of work, gender and interprofessional learning experience are described in the table as follows:

1. Characteristics of Research Respondents

\begin{tabular}{lcc}
\hline Characteristics Respondents & $\mathrm{f}$ & $(\%)$ \\
\hline Program Study & & \\
- Nursing & 8 & 40 \\
- Midwifery & 8 & 40 \\
- Health Nutrition & 4 & 20 \\
Length of work & & \\
- 5-10 years & 16 & 80 \\
- 11-15 years & 3 & 15 \\
- 16-20 years & 1 & 5 \\
Gender & 2 & \\
$\quad$ - Man & 18 & 10 \\
- Woman & 7 & 90 \\
Interprofessional experience & & \\
- Yes & 13 & 35 \\
- Never & & 65 \\
\hline (n=20) &
\end{tabular}

Distribution of respondent characteristics refers to a similar study conducted by Curran et al (2007), the results of the study mention that several types of characteristics related to the attitude and readiness of lecturers towards interprofessional cooperation are gender and previous work experience of interdisciplinary collaboration. Turner (1999) states that professional background influences IPE readiness. Thoha (in Fauziah, 2010) asserts that differences in the characteristics of respondents cause differences in perceiving something, including perceptions and readiness for IPE.

2. Readiness of Lecturers as Interprofessional Education Learning Facilitators in Antenatal Care

Interventions carried out in this study were to improve readiness in facilitating interprofessional learning by holding an interprofessional learning training that was supplemented by role play cases. Antenatal care was used as a trigger case in this study. Measurement of lecturer readiness was measured using the Readiness 
Interprofessional Learning Scale (RIPLS) instrument. Based on the results of statistical tests using the T-Test there are differences in the readiness of the lecturer between before and after being given an intervention in the form of interprofessional education (IPE) training on the entire lecturer with pvalue $=0.021$. In this study the attitude of the lecturer was measured using the RIPLS questionnaire where data collection was carried out 2 times (pretest and posttest). Test results statistically show that all lecturers show a positive attitude to be a facilitator of interprofessional learning. The mean value shows close to 95 (pretest $=82.83$; posttest $1=87.22$; where the value 95 indicates that the student's attitude is more positive.

Instrument to measure the component of readiness in the Readiness Interprofessional Learning Scale (RIPLS) consists of three sub-variables namely cooperation and collaboration, professional identity and roles and responsibilities (Parsell \& Bligh, 1999). Based on the results in this study shows the value of $p$ in the sub-variables of collaboration and collaboration $(p=0.001)$ and professional identity ( $p$ $=0.003$ ) significantly increased, but not in the sub-variables of roles and responsibilities $(\mathrm{p}=0.210)$.

3. Comparison of Readiness of Interprofessional Education Facilitators in Antenatal Care

Comparison of the readiness of lecturers to IPE in each department using the Kruskall-Wallis test because the data distribution is not normal. The test results show that there is no significant difference in the perception of the readiness of lecturers in each department $(p=0.685)$. A comparative test was conducted to determine the differences in the readiness of lecturers towards IPE between the three departments. From the results of the Kruskall-Wallis test, $p=0.685$ which can be interpreted that there is no difference in the value of the readiness of the lecturer to facilitate meaningful IPE between two groups of teaching places

\section{DISCUSSION}

1. Readiness of Lecturers as Interprofessional Education Learning Facilitators in Antenatal Care.

A more in-depth discussion is carried out on each component of preparedness for IPE. Through a deeper analysis of the components which include: 1) cooperation and collaboration, 2) professional identity and 3) roles and responsibilities, all components of the readiness of lecturers towards IPE are in the good category.

The collaboration and collaboration sub-variables are known to have a significant $\mathrm{p}$ value at all data collection times. This shows that the lecturer experienced a significant increase in the statement to facilitate the collaboration and collaboration component after the intervention. As revealed by Barr (1998), that one outcome expected in the implementation of IPE is the occurrence of strong collaboration and collaboration between health professionals, especially from different disciplines. Respondents in this study mostly showed a positive attitude that interdisciplinary learning in the classroom would help them become members of a better health care team.

Sub variables in professional identity have increased in pre-post data retrieval $(\mathrm{p}=0.001)$. Professional identity reflects the importance of professional profession identity to define the life and cultural strength of each individual's profession. Morison 
et al., (2004) states that medical, nursing and health nutrition students are more likely to have a strong sense of association with their own professional roles after obtaining IPE training. Similarly, Coster et al. (2008) stated that students who have a positive professional identity towards IPE while at the academic stage will be more interested in collaborating with other professional students, because they bring more positive perceptions when entering clinical education. Important moments for the future development of professional identity occur at the beginning of professional and career training. Therefore, it is very important to create an effort to foster readiness for facilitators and strengthen confidence in positive professional identities.

Sub-variables of professional roles did not experience significant changes $(p=$ 0.210) after attending IPE training. The absence of changes in the role and professional responsibility sub-variables can be influenced by the short time of the IPE training, so that lecturers have not experienced the process of internalizing the role of facilitator to the fullest. Barr (1998) explains that lecturers with good readiness to facilitate IPE will help students to achieve the expected IPE competencies. Readiness measurement uses 19 statements with choices "Strongly Agree", "Agree", "Disagree" and "Strongly Disagree". From this statement, it is known that the answers of respondents who approached strongly agree, namely: 1) "the ability of teamwork is very important"; 2) "studying with other health profession students will help students become members of a better health care team". Conversely, disagreeing answers appear in the statement: 1) "not important for students of the health profession to study together" and 2) "I do not want to waste my time educating students in other professions". Both of these questions are negative questions. So, the respondent's answer shows that the lecturer is aware of the importance of learning to collaborate. The thing that needs to be considered in this IPE learning is the clarity of competency standards that must be achieved by the students themselves, so that the existence of IPE will clarify the contribution of every health profession in the health care system. This is like the statement of Soedyowinarso (2011) that although IPE is designed for groups, ultimately it aims to develop each individual. This is similar to the results of research conducted by Aryakhiyati (2011) which shows the teamwork and collaboration components have the highest value while the roles and responsibilities have the lowest value in the lecturers of Gadjah Mada University Medical Faculty. The highest value shown in the teamwork component and collaboration can be assumed that the lecturer has realized that the importance of IPE. Integrated learning models, such as IPE, can make students ready to work in teams. As one of the competencies that must be possessed by a student in IPE, it is expected that each student has the ability to: 1) various resources, skills and responsibilities to achieve common goals in collaborative practice, 2) build commitment and maintain participation in an interprofessional team, 3) recognize when there is a discrepancy in collaboration practices, 4) overcome problems and conflicts using appropriate problem solving and conflict management techniques, 5) use decision making that is in accordance with the collaboration team (Interprofessional Education Consortium, in Fauziah, 2010). The low value shown in the role component and responsibility can be assumed that understanding between health professionals about the role of each health profession in the lecturer needs to be improved. An understanding of the roles and responsibilities of each profession makes health professionals understand what each profession will actually do in its work (Gilbert et al, 2005). Knowledge of the roles and responsibilities of each profession 
makes the implementers of IPE learning more ready to work together in teams (Morison et al, 2003).

2. Comparison of Readiness of Interprofessional Education Facilitators in Antenatal Care

This result is different from the research conducted by Aryakhiyati (2011) which shows that there are significant differences with $p=0.032$. Post Hoc analysis shows that there is a mean difference in the value of readiness of medical and nursing lecturers as well as differences in average readiness values of medical and nutrition lecturers' readiness.

The implementation of IPE urgently requires role models, namely teaching lecturers who are committed to IPE and learning environments that support the creation of teamwork and are able to combine theory and prakatik (Gaudet et al, in Aryakhiyati, 2011). Good readiness from all lecturers on IPE implementation is the potential to develop this IPE learning model.

The comparative test results of the teacher's readiness to facilitate IPE based on the characteristics of respondents including gender, collaborative experience and length of teaching showed no significant differences. This result is different from the results of research conducted by Curran et al (2007) which states that there are significant differences in lecturer readiness between male and female lecturers. Female lecturers have a higher average attitude score. Aryakhiyati (2011) also shows that there is a significant difference in the value of the readiness of lecturers at the Faculty of Medicine UGM based on teaching experience. The difference in the readiness of the lecturers towards the implementation of IPE still varies between age and collaborative experience. Gender and collaborative experience from previous research cannot be used as a reference in making conclusions.

\section{CONCLUSIONS}

Based on the discussion discussed, it can be concluded that the majority of respondents from Nursing and Midwifery majors, female, do not have collaborative work experience, with a minimum of experience of less than or equal to 5-10 years. Lecturers have positive readiness for IPE. Educational institutions are recommended to start developing models that are mutually agreed upon and supported by facilities and clear policies and regulations. Subsequent research is expected to explore more appropriate IPE learning models through both qualitative and quantitative approaches.

\section{ACKNOWLEDGEMENTS}

Thanks to the Ministry of Research, Technology, and Higher Education Republic of Indonesia for the support for this research (Ristekdikti).

\section{REFERENCES}

Aryakhiyati, N. (2011). Analisis sikap dan kesiapan dosen FK UGM terhadap interprofessional education (IPE). Skripsi Program Studi Ilmu Keperawatan Fakultas Kedokteran Universitas Gadjah Mada.

Armiatin., 2013. Rantai Efek Peningkatan Mutu dalam Keselamatan Ibu dan Anak. Artikel Publikasi 4 maret 2013. Diakses pada 11 Mei 2018.

Barr, H. (1998). Competent to collaborate: Towards a competencybased model for interprofessional education. Journal of Interprofessional Care, 12,181-187. 
Baker, C., Pulling, C., McGraw, R., Dagnone, J. D., Hopkins-Rosseel, D., \&Medves, J . 2008. Simulation in Interprofessional Education for Patient- Centred Collaborative Care. Journal of Advanced Nursing: 64(4); 372-379.

Curran, V.R. Deacon, D.R. \& Fleet, L. (2007). Attitudes of health sciences faculty members towards interprofessional teamwork and education. Learning in Health and Social care, 7 (3):145-156. Dahlan, S. (2012). Statistik untuk Kedokteran dan Kesehatan. Seri Evidence Based Medicine 1. Edisi 5. Jakarta: Salemba Medika.

Departemen Kesehatan Republik Indonesia. 2008. Pedoman Operasional: Pelayanan Terpadu Kesehatan Reproduksi di Puskesmas. Jakarta.

Fauziah, F.A. (2010). Analisis gambaran persepsi dan kesiapan mahasiswa profesi FK UGM terhadap interprofessional education di tatanan pendidikan klinik. Skripsi Program Studi Ilmu Keperawatan Fakultas Kedokteran Universitas Gadjah

Freeman, S., Wright A., Lindqvist, S., 2010. Facilitator training for educators involved in interprofessional learning. Journal of Interprofessional Care, July 2010; 24(4): 375385.

Freeth, D., Hammick, M., Reeves, S., Koppel, I., Barr, H (2005). Effective Interprofessional Education: Development, Delivery and Evaluation. Canada. Blackwell Publishing.

Godden-Webster, A. \& Murphy, G. (2014). Interprofessional Collaboration in Practice: A guide for strengthening student learning experiences. Halifax, Nova Scotia: Dahlhousie University, Faculty of Health Professions.

Liaw, Zhou, Lau, Siau, Chan. (2013) An interprofessional communication training using simulation to enhance safe care for a deteriorating patient, Nurse Education Today, diakses dari http://dx.doi.org/10.1016/j.nedt.2013.02.019 pada tanggal 2 April 2018.

Morison, S., Boohan, M., Moutray, M., \& Jenkins, J. (2004). Developing prequalification inter-professional education for nursing and medical medical students: Sampling student attitudes to guide development. Nurse Education in Practice, 4, 2029

Prentice, D., Taplay, K., Horsley, E., Payeur-Grenier, S., \& Belford, D. (2011, March). Interprofessional simulation: An effective training experience for health care professionals working in community hospitals. Clinical Simulation in Nursing, 7(2), e61-e67. doi:10.1016/j.ecns.2010.03.001.

Sedyowinarso, M., Fauziah, F. A., Aryakhiyati, N., Julica, M. P., Sulistyowati, E., Masriati, F. N., Olam, S. J., Dini, C., Afifah, M., Meisudi, R., \& Piscesa, S. (2011). Persepsi dan kesiapan mahasiswa dan dosen profesi kesehatan terhadap model pembelajaran pendidikan interprofesi. Proyek HPEQ-Dikti.

Sukmawati, F., Purnami dan Nugroho., 2012. Sistem Informasi Geografis Jejaring Rujukan Ibu Dirujuk Dan Karakteristiknya Di Kota Semarang Tahun 2011. Jurnal Kesehatan Masyarakat, Volume 1, Nomor 2, Tahun 2012, Halaman 163-176. Diakses dari http://ejournals1.undip.ac.id. pada tanggal 11 Mei 2018.

Susilaningsih, F,. Mukhlas., Sunartini dan Utarini., 2011. Nurse-Physician Collaborative Practice in Interdisciplinary Model Of Patient Care. Jurnal Manajemen Pelayanan Kesehatan volume 14 No. 02 Juni 2011 Halaman 92 - 98.

Wagner, J., Liston, B. \& Miller, J., 2011. Developing Interprofessional Communication Skills. Teaching and Learning in Nursing, 6(3), pp.97-101. Diakses dari: http://linkinghub.elsevier.com/retrieve/pii. pada tanggal 25 Mei 2018.

World Health Organization. (2010) Framework for action on interprofessional education and collaborative practice. Geneva, Switzerland: WHO 